This article was downloaded by: [Australian National University Library]

On: 11 September 2009

Access details: Access Details: [subscription number 907447645]

Publisher Routledge

Informa Ltd Registered in England and Wales Registered Number: 1072954 Registered office: Mortimer House, 37-41 Mortimer Street, London W1T 3JH, UK

\section{Survival $=$}

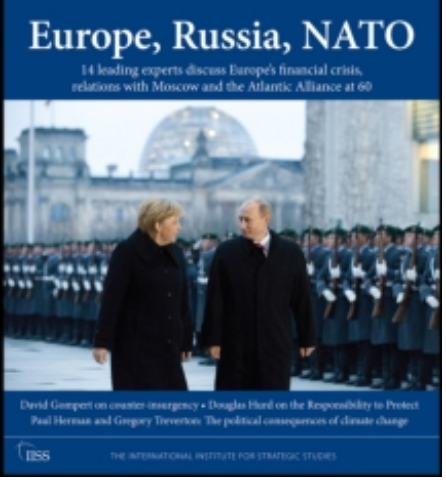

\section{Survival}

Publication details, including instructions for authors and subscription information: http://www.informaworld.com/smpp/title content=t713659919

\section{Carrying China's Torch \\ Robert Ayson; Brendan Taylor}

Online Publication Date: 01 August 2008

To cite this Article Ayson, Robert and Taylor, Brendan(2008)'Carrying China's Torch',Survival,50:4,5 — 10

To link to this Article: DOI: $10.1080 / 00396330802328776$

URL: http://dx.doi.org/10.1080/00396330802328776

PLEASE SCROLL DOWN FOR ARTICLE

Full terms and conditions of use: http://www.informaworld.com/terms-and-conditions-of-access.pdf

This article may be used for research, teaching and private study purposes. Any substantial or systematic reproduction, re-distribution, re-selling, loan or sub-licensing, systematic supply or distribution in any form to anyone is expressly forbidden.

The publisher does not give any warranty express or implied or make any representation that the contents will be complete or accurate or up to date. The accuracy of any instructions, formulae and drug doses should be independently verified with primary sources. The publisher shall not be liable for any loss, actions, claims, proceedings, demand or costs or damages whatsoever or howsoever caused arising directly or indirectly in connection with or arising out of the use of this material. 


\title{
Carrying China's Torch
}

\author{
Robert Ayson and Brendan Taylor
}

China's government has gained international recognition for what appeared to be a swift, coordinated and in many ways sensitive response to the Sichuan earthquake. In contrast to the refusal of Myanmar's ruling junta to acknowledge the scale of the devastation caused by recent floods and to make the most of sincere offers of international assistance, Beijing's leaders came across as much more transparent, accountable and responsible managers of a serious natural disaster. In the lead-up to the August Olympics, China's international reputation has received an unplanned boost.

The earthquake and its aftermath diverted attention from China's very long and laboured Olympic torch relay. Beijing's leaders expected the relay to be a triumphant prelude to the 29th Olympiad, an event intended to confirm China's status as a genuine great power. But the 2008 procession quickly descended into farce. The torch's passage was disrupted by demonstrations, particularly in early portions of the relay through London and Paris. As the relay went on, local governments, most notably in China's Asian neighbourhood, contrived to make the torch's journey as benign as possible by, for instance, curtailing routes and directing runners along safer and more predictable pathways. At the surreal extreme was the Mount Everest leg, which had been years in the planning, employing 80 space scientists and costing millions. Well before a special high-altitude torch was taken to the summit, Everest was effectively shut down. Chinese authorities banned climbers

Robert Ayson and Brendan Taylor are scholars with the Australian National University's Strategic and Defence Studies Centre. 
from the northern side of the mountain and restricted media coverage of the event from Tibet. Following Beijing's lead, Nepalese authorities deployed two dozen armed security personnel, enforced a no-climb rule above Camp 2 (at an altitude of 6,500 metres), and banned laptops and satellite and Internet communications from Base Camp on the southern side of the mountain. Through the fog of censorship a report from one alpinist suggested that China had also sent security personnel to Everest's Nepalese flank.

The relay has been a test of how various communities around the world see China. In contrast with the near universal sympathy the country received after the earthquake, the mixed experiences of the relay have been a more accurate measure of the international reception China can expect as its power grows.

The torch relay left little doubt about China's very considerable aspirations and reveals much about Chinese power today. Most impressive and yet largely unanticipated was the mobilisation of the Chinese diaspora, particularly on the South Korean and Australian legs. In Australia, thousands of Chinese students arrived early and en masse to secure pre-determined vantage points along the relay's route. Enthusiastically waving embassysupplied flags and patriotically screaming 'One China', these loyal young cadres outnumbered and strategically out-positioned their 'splittist' counterparts. In so doing, they reminded the world that quantity has a quality all of its own.

The relay has also underlined the potency of China's growing economic power. Corporate sponsors contributed an estimated \$15 million to the relay, and refused to be cornered into criticising Beijing or withdrawing their support, even as hopes for the torch's 'harmonious journey' vanished. The reasons for their reluctance became obvious when rumours surfaced that the French retailer Carrefour was bankrolling the Dalai Lama. Many Chinese citizens responded by boycotting the supermarket chain, and nationwide protests erupted outside Carrefour stores. Somewhat unsurprisingly, Carrefour rapidly doused these allegations and pledged its unswerving allegiance to the Beijing Olympics.

These protests, while short-lived, further highlighted some of the sources and limits of Chinese power. That they were organised using mobile phones 
and the Internet is somewhat ironic. Traditionally, such technologies have been considered the 'Achilles' heel' of the Chinese government. They have been portrayed as a threat to Beijing's longstanding stranglehold on information and a conduit for the dissemination of new political ideas throughout China.

During the torch relay, however, mobile phones and the Internet were used not to undermine, but to rally support for the Chinese leadership. They have also served as a catalyst for Chinese nationalism more generally. Yet the manner in which Beijing has sought to regulate the resultant outpourings of patriotic sentiment also suggests an ongoing sense of vulnerability. Having allowed the anti-Carrefour protests to run for several days, Beijing abruptly ordered a cessation of such activities. Mobile phone messages and Internet chat rooms referring to the French retailer were also reportedly blocked. This pattern is consistent with Beijing's response to the mass anti-Japanese protests of April 2005. The Chinese Communist Party is not entirely sure whether popular nationalism is a useful force that can be utilised and even encouraged to provide legitimacy in a post-socialist era, or a dangerous beast that can easily run out of control.

The centre of

Beijing was not the only Asian capital seeking to regulate popular sentiment during the torch relay. On the Indian leg, for instance, the centre of New Delhi went into complete lockdown. Fifteen thousand security personnel were deployed and almost 300 protestors

New Delhi went into complete lockdown (mostly Tibetan) were arrested. Manmohan Singh's government, eager to preserve and build on improvements in its vital relationship with China, also publicly advised the Dalai Lama to take a low-key role. In Indonesia, the relay was held within the confines of the Bung Karno sports stadium, with only 2,500 'guests', and the same number of security personnel, in attendance.

Security was also tight in the Japanese city of Nagano, with authorities deploying 3,00o police and shutting the public out at torch stopping points. Still, a major Japanese temple refused to host the torch as planned, and scuffles between Chinese students and Japanese nationalists broke out on the 
fringes of the relay. But given the proven potential of the underlying tension in Sino-Japanese relations to produce large-scale protests in both countries, the relatively smooth Nagano leg was no small achievement. Overall, while security measures in Asian countries were partly a reflection of concerns about domestic order, they also indicated a sense of deference to China's Olympic sensibilities. This in itself is testament to China's growing power and influence in the region.

South Korea proved the unexpected exception to this Asian rule. In Seoul, 8,300 police were unable to prevent Chinese students from assaulting a small number of local protesters, prompting threats of deportation from the South Korean government and official complaints to Beijing's ambassador. Yet these diplomatic gymnastics paled in comparison with the defiance that greeted the torch on its 'disharmonious' journey through Europe. A Paris-based media-rights group disrupted the torch-lighting ceremony in Olympia, unfurling a banner criticising Chinese human-rights practices; members of China's 'Sacred Torch Protection Unit' were labelled 'thugs' by the head of London's Olympic organising committee, Sebastian Coe, even as anti-China protesters tried to extinguish the torch during its journey through the city; and the cover of the prominent German magazine Der Spiegel depicted China's leaders beneath Olympic rings made of barbed wire.

Perhaps most controversially, China's 'angel in a wheelchair' - the paraplegic fencer Jin Jing - was jostled by pro-Tibetan protesters while carrying the torch through Paris. Despite issuing an apology and inviting Jin to return to France, President Nicolas Sarkozy continued to lead calls for a boycott of the Olympic opening ceremony. British Prime Minister Gordon Brown and German Chancellor Angela Merkel were quick to take up the baton, publicly confirming their non-attendance. These developments have given rise to a worrying spike in anti-Western sentiment within China. This feeling has been further fuelled by a widely held perception of Western media bias, epitomised by CNN commentator Jack Cafferty's characterisation of China's leaders as a 'bunch of thugs and goons'.

Princeton professor John Ikenberry recently argued that a rare opportunity exists to integrate an increasingly powerful China into the current 
Western-led international order. To the extent that this window exists, it may close quickly if growing numbers of Chinese citizens do not feel that their country is respected or wanted as a member of that order, and especially if they imagine a Western conspiracy designed to keep their nation shackled.

'The West' is a heterogeneous amalgam and the varying reactions of some Western leaders to the torch relay have been significantly more nuanced than the popular Chinese view suggests. Most intriguing has been the approach taken by Australian Prime Minister Kevin Rudd. Since his election late last year, Rudd has been caricatured as a 'Manchurian candidate' because of his fluency in Mandarin and strong interest in China. Yet he surprised many with the fairly robust approach he took during Australia's turn with the torch. In the days prior to the Canberra leg of the relay, Rudd and his spokespeople repeatedly corrected Chinese officials over the role of the 'Sacred Torch Protection Unit'. He publicly threatened to arrest any members of this paramilitary squad who sought to play a direct security role. And when two members of the infamous blue-track-suited brigade tried to get close to the flame during the relay, they were forcibly removed by Australian Federal Police officers.

What distinguishes Rudd from his European counterparts is his sophisticated understanding of Beijing's 'red lines' in relation to the Olympic games and the Tibet issue. Speaking to a group of Peking University students in March of this year, Rudd openly acknowledged Tibet's 'significant humanrights problems'. But at the same time, he described himself as a zhenghou (true friend) of China and delivered his criticisms in that capacity. He also reaffirmed Australia's recognition of China's sovereignty over Tibet. Most importantly, he stated his opposition to boycotting the Olympics. In so doing, Rudd demonstrated his understanding of the symbolic importance of the upcoming Olympics to China. He is a student of Chinese history and knows well that this is the platform from which China will announce its arrival as a great power and shed its 'victim mentality' resulting from a 'century of shame' under Western domination.

Similarities are evident in Washington's response to the torch relay, although some aspects of the US tour echoed the European experience. The San Francisco leg, for instance, was marred by violent clashes which evoked 
memories of Paris and London. Pro-Tibetan congressional supporters, led by House Speaker Nancy Pelosi, have urged President Bush to boycott the games, as have presidential hopefuls John McCain and Barack Obama. Yet Bush's response to this mounting pressure has been most revealing. He has declined to openly politicise the Olympics, indicating that US pressure regarding Beijing's approach to Tibet has been and will continue to be exerted in private. Like Rudd, Bush appears to be pursuing a more sophisticated 'third way' between indulging and directly confronting China's Olympic sensibilities.

By contrast, China's heavy-handed approach during the torch relay is at odds with its own sophisticated diplomacy in recent years. Yet despite the public-relations disaster which parts of the torch relay have become for China's foreign relations - Pew polling data collected in March and April, for instance, shows a sudden spike in global anxieties over China's growing power - the domestic advantages for Beijing have made it a game worth the candle. It is no coincidence that six weeks of the relay have been dedicated to running the Olympic torch through 46 major Chinese cities, where it has been largely greeted by further displays of patriotism.

The Sichuan earthquake has also helped reinforce a sense of national unity and took much heat out of the criticism China attracted from some quarters over the torch relay. But the relay's broader strategic significance should not be lost amidst the rubble of this terrible natural tragedy. The torch's travels reveal much about the sources and limits of Chinese power, demonstrating just how intense the fires of Chinese nationalism can be when fanned. They provide important insights into the potentially combustible nature of ties between China and the West. Most importantly, the relay sheds new light on approaches for dealing with a China increasingly fearful that its Olympic dream, and the international re-emergence it symbolises, might still backfire.

When Nazi Germany invented the Olympic torch relay in 1936, sending it eastward, the New York Times presciently dubbed its route a 'strategic highway'. China's 2008 relay - and the controversies it sparked - are no less revealing about a quite different regime whose growing power promises to define a new era in world affairs. 